\title{
Pelanggaran Prinsip Utmost Good Faith Dan Waiting Period Pada Asuransi Jiwa (Studi Kasus Putusan No. 138/PDT.G/2012/PN.PDG)
}

\author{
Satria Azis Widiarto \\ Universitas Hukum Ekonomi Universitas Indonesia \\ satriaazis96@gmail.com, satria.azis91@ui.ac.id
}

\begin{abstract}
Abstrak. Artikel ini membahas mengenai (1) pelanggaran prinsip Utmost Good Faith sebagai dasar untuk menolak klaim tertanggung dalam sengketa asuransi jiwa antara Endry Suryanti melawan PT. Asuransi Allianz Life Indonesia sudah tepat penerapannya menurut hukum asuransi. Kemudian (2) dampak hukum penerapan Waiting Period pada polis asuransi No. 000012400302 atas nama Erisman terhadap tanggung jawab polis, serta (3) penerapan prinsip Utmost Good Faith dalam putusan nomor 138/pdt.g/2012/Pn.Pdg. Penelitian ini menggunakan metode yuridis-normatif, dimana data penelitian sebagian besar berasal dari studi kepustakaan. Hasil penelitian ini adalah (1) Pelanggaran prinsip Utmost Good Faith sebagai dasar bagi PT. Allianz Life Indonesia untuk menolak klaim Erisman sudah sesuai menurut hukum asuransi, (2) dampak hukum waiting period terhadap tanggung jawab polis adalah Penanggung tidak wajib memberikan maslahat (manfaat/klaim) meninggal karena belum tercapai masa waktu tertentu, serta (3) penerapan prinsip Utmost Good Faith belum dilakukan oleh Majelis Hakim karena masa polis asuransi Erisman belum mencapai waktu tertentu sebagaimana ketentuan pasal 2 polis asuransi dan Penggugat tidak dapat membuktikan dalil gugatannya di persidangan sehingga tidak ada relevansi nya mempertimbangkan bukti Tergugat lainnya.
\end{abstract}

Kata Kunci: Asuransi, Prinsip Utmost Good Faith, Keterangan yang Tidak Benar, Waiting Period, Polis Asuransi,

Abstrak. This Article discusses about (1) the breach of Utmost Good Faith principle as base to reject claim of the Insured in life insurance dispute between Endry Suryanti against PT. Allianz Life Insurance Indonesia. Then (2) the legal effect on the application of Waiting Period on insurance policy No. 000012400302 on behalf of Erisman towards the responsibility of the policy, and (3) the application of Utmost Good Faith principle in Verdict No. 138/Pdt.g/2012/Pn.Pdg. This research uses juridical-normative method, where research data mostly come from literature study. The results of this study are (1) the Breach of Utmost Good Faith principle as the basis for PT. Allianz Life Indonesia to refuse Erisman's claim is in accordance with the insurance law, (2) the legal effect of the waiting period towards the responsibility of the policy is that the Insurer is not obliged to provide the benefits of death because it has not reached a certain period of time, and (3) the application of the Utmost Good Faith principle has not been done by the Panel of Judges because the period of Erisman's insurance policy has not reached a certain time as stipulated in article 2 of the insurance policy and the Plaintiff can not prove the argument of its lawsuit in the hearing so that its relevance does not consider the other Defendant's evidence.

Keywords: Insurance, Utmost Good Faith Principle, Inaccurate Information, Waiting Period, Insurance Policy,

\section{PENDAHULUAN}

Kehidupan manusia itu selalu berkisar antara ketidakpastian yang berkepanjangan dan terus menerus, keadaan tidak pasti tersebut lazim disebut sebagai suatu risiko. Manusia selalu mengahadapi risiko karena memang pada hakikatnya manusia merupakan suatu objek tumpukan risiko, sebagaimana sifat hakiki manusia itu sendiri. Maka risiko memang merupakan suatu hal yang tidak dapat 
dipisahkan dari kehidupan manusia. Menurut R. Subekti dan R. Tjitrosudibio, risiko adalah kewajiban menanggung atau memikul kerugian sebagai akibat sesuatu peristiwa diluar kesalahannya, yang menimpa barang yang menjadi objek perjanjian.

Risiko merupakan hal yang tidak dapat dipisahkan dari manusia karena tidak ada seorang pun yang dapat bebas dari suatu risiko. Sri Rejeki Hartono mengkategorikan Risiko berdasarkan akibatnya yaitu terdiri dari risiko fundamental dan risiko khusus. Risiko fundamental biasanya mempengaruhi masyarakat atau kelompok-kelompok orang yang mana tidak dapat diawasi atau dideteksi oleh perorangan. Risiko fundamental pada umumnya diakibatkan oleh bencana alam atau situasi ekonomi yang luas. Sedangkan risiko khusus merupakan risiko yang diakibatkan karena keputusan seseorang atau karena tindakannya. Maka dari itu risiko khusus ini menjadi tanggung jawab perorangan pula. Misalnya karena kurang hati-hatinya seorang pengendara yang melajukan kendaraannya pada kecepatan tinggi lalu menabrak pembatas jalan. Cara mengatasi risiko itu terdiri dari berbagai macam seperti menghindari, menyingkir, atau menjauhi (avoidance), mencegah (prevention), mengalihkan (transfer), dan menerima (assumption or retention).

Cara yang tepat mengatasi risiko adalah dengan mengalihkannya kepada penanggung atau perusahaan asuransi. Asuransi merupakan suatu perjanjian yang tidak terpisahkan dari kehidupan manusia saat ini. Asuransi atau dalam bahasa belanda 'verzekering' berarti pertanggungan. Asuransi merupakan perjanjian antara dua pihak, yaitu Penanggung dan Tertanggung, atau perusahaan asuransi dengan pemegang polis, yang menjadi dasar penerimaan premi oleh perusahaan asuransi sebagai imbalan untuk memberikan pembayaran yang didasarkan pada meninggalnya tertanggung, atau pembayaran yang didasarkan pada hidupnya tertanggung dengan manfaat yang besarnya telah ditetapkan dan/atau didasarkan pada hasil pengelolaan dana. Dalam suatu perjanjian asuransi terdapat dua pihak yakni pihak
Penanggung dan pihak Tertanggung. Pihak Penanggung merupakan pihak yang menjanjikan akan memberikan pembayaran atas kerugian-kerugian atau akan menyediakan jasa-jasanya atau perusahaan asuransi. Sedangkan Tertanggung berkewajiban membayar sejumlah uang atau premi sebagai penggantian dari risiko tersebut. Dalam pelaksanaan nya, Tertanggung diwajibkan memberikan kondisi yang sebenar-benarnya berdasarkan fakta yang ada atas objek yang akan dipertanggunkan kepada Penanggung.

Dalam asuransi jiwa, Tertanggung harus mengisi Surat Permintaan Asuransi Jiwa (SPAJ). Di dalam SPAJ tersebut terdapat data pribadi calon pemegang polis, data pertanggungan dan premi asuransi, data sumber pembayaran premi, data yang ditunjuk untuk menerima manfaat asuransi, hingga data mengenai kesehatan calon pemegang polis. SPAJ tersebut harus diisi sesuai dengan yang sebenarnya. Misalnya tinggi dan berat badannya berapa, apa saja riwayat penyakit yang pernah di derita, dan lain-lain. Setelah pengisian formulir permohonan penutupan asuransi, pihak Tertanggung akan dimintai keterangan oleh field underwriter terkait isi dari formulir permohonan penutupan asuransi tersebut. Kemudian Tertanggung akan diberitahu mengenai aplikasi nya tersebut, jika disetujui maka Tertanggung akan dibertahu jumlah premi yang harus dibayarkannya.

Risiko dalam asuransi jiwa biasanya memiliki dua pola yakni dalam pola pertama jika nilai pertanggungannya kecil maka Penanggung cukup puas dengan SPAJ dan penanggung mengandalkan pada apa yang diisi dalam SPAJ. Dalam pola kedua jika nilai pertanggungan besar maka selain dari pengisian SPAJ, biasanya penanggung akan meminta informasi lainnya seperti medical check up tertanggung.

Dalam hukum asuransi terdapat beberapa prinsip seperti prinsip insurable interest, Utmost good faith, dan indemnitas. Prinsip insurable interest yakni tertanggung harus memiliki kepentingan terhadap objek yang ditanggungkannya. Prinsip Indemnitas yaitu Penanggung berkewajiban memulihkan kerugian yang dialami tertanggung. 
Sedangkan Prinsip Utmost good faith adalah setiap pihak diwajibkan untuk mengungkapkan segala fakta materil atau fakta yang dapat mempengaruhi penutupan asuransi terhadap suatu objek (duty of disclosure) dan dilarang membuat pernyataan yang keliru atau tidak benar (misrepresentation) dalam perjanjian asuransi

Dalam perjanjian asuransi, tentunya kita tidak lepas dari pembahasan mengenai Klaim. Klaim merupakan tuntutan yang diajukan Tertanggung kepada Penanggung atau perusahaan asuransi atas kerugian yang dideritanya sebagai akibat atau rusaknya sesuatu harta benda yang dipertanggungkan, karena peristiwa yang diperjanjikan, selesainya masa kontrak asuransi dan tuntutan ganti rugi dari pihak ketiga; tuntutan penggantian oleh perorangan atau perusahaan asuransi dibawah ketentuan polis. Dalam pelaksanaannya, terdapat beberapa kasus penolakan klaim asuransi yang terjadi dikarenakan Tertanggung tidak jujur ketika mengisi formulir penutupan asuransi, seperti halnya pada putusan no $1040 \mathrm{~K} / \mathrm{Pdt} / 2014$, 606/pdt.g/2012/Pn.Jkt.Sel dan 138/Pdt/2012/PN.Pdg. Prinsip Utmost Good Faith sendiri diatur pada pasal 251 Kitab Undang-Undang Hukum Dagang (KUHD) yang intinya menyatakan bahwa batalnya pertanggungan karena terdapat material misrepresentation dan material nondisclosure/ concealment.

$$
\text { Pada perkara nomor }
$$

138/Pdt.g/2012/PN.Pdg Penggugat selaku istri dari Alm. Erisman menggugat PT Asuransi Allianz Life Indonesia (selaku Penanggung) karena Penanggung tidak mau mengeluarkan uang pertanggungan pada saat Erisman meninggal dunia. Pada saat pengisian permohonan penutupan asuransi, Erisman telah menjelaskan bahwa ia tidak pernah menderita penyakit seperti jantung berdebardebar, serangan jantung dan lainnya sebagaimana termuat dalam putusan. Erisman juga telah melakukan membayarkan premi selama 17 kali walaupun sempat menuggak selama enam bulan dan telah dilakukan pemulihan polis. Akan tetapi hingga Erisman meninggal dunia, pihak Penanggung tak juga memberikan uang pertanggungan karena dalam perjanjian terdapat klausul yang menerangkan bahwa pihak Penanggung berhak membatalkan polis serta tidak membayarkan maslahat (manfaat/klaim) meninggal jika pertanggungan belum berlaku selama 2 tahun sejak tanggal terbit polis atau pemulihan polis.

Berdasarkan pemaparan diatas, maka melalui Artikel ini Penulis ingin membahas secara lebih mendalam mengenai prinsip utmost good faith dan waiting period pada perjanjian asuransi jiwa, khususnya dalam putusan 138/Pdt.g/2012/PN.Pdg dengan rumusan masalah sebagai berikut:

1. Apakah pelanggaran Prinsip Utmost Good Faith sebagai dasar untuk menolak klaim tertanggung dalam sengketa asuransi jiwa antara Endry Suryanti melawan PT Asuransi Allianz life Indonesia sudah tepat menurut hukum asuransi?

2. Bagaimana dampak hukum waiting period dari polis asuransi No 000012400302 atas nama Erisman terhadap tanggung jawab polis?

3. Bagaimana penerapan Prinsip Utmost Good Faith dalam putusan no 138/Pdt.g/2012/pn.pdg?

Dalam artikel ini, tujuan umum penulis yaitu untuk menambah pengetahuan dan wawasan mengenai Hukum Asuransi di Indonesia. Sedangkan tujuan khusus dalam artikel ini adalah

1. untuk mengetahui apakah pelanggaran prinsip utmost good faith sebagai dasar untuk menolak klaim Tertanggung dalam sengketa asuransi jiwa antara Endry Suryanti melawan PT. Asuransi Allianz Life Indonesia sudah tepat menurut hukum asuransi,

2. untuk mengetahui bagaimana dampak hukum waiting period dari polis asuransi No. 000012400302 atas nama Erisman terhadap tanggung jawab polis,

3. untuk mengetahui bagaimana penerapan prinsip utmost good faith dalam putusah No. 138/Pdt.G/2012/Pn.Pdg.

METODE PENELITIAN (12pt) 
Metode yang digunakan dalam penulisan artikel ini adalah metode pendekatan yuridis normatif. Yuridis normatif yaitu penulisan karya ilmiah yang didasarkan pada studi kepustakaan dan mencari konsep-konsep, pendapat-pendapat ataupun penemuan yang berhubungan dengan permasalahan hukum. Penulis mengkaji prosedural hukum berdasarkan bahan hukum yang dilakukan dengan pengumpulan bahan hukum secara studi kepustakaan yang berkaitan dengan prinsip utmost good faith dan waiting period pada asuransi jiwa.

\section{HASIL DAN PEMBAHASAN}

\section{Analisis Pelanggaran Prinsip Utmost Good Faith Sebagai Dasar Untuk Menolak Klaim Tertanggung Dalam Sengketa Asuransi Jiwa antara Endry Suryanti melawan PT. Asuransi Allianz Life Indonesia Sudah Tepat Menurut Hukum Asuransi.}

Pada gugatan Endry Suryanti (Penggugat) yang merupakan Istri/ ahli waris dari Alm Erisman, menyatakan bahwa Bapak Erisman (Alm) sebagai pemegang polis asuransi No 000012400302 telah mengecek kesehatannya oleh dokter yang ditunjuk oleh Tergugat dan hasilnya adalah Bapak Erisman (Alm) terbebas dari penyakit nyeri dada, sesak napas, jantung berdebar-debar, serangan jantung, tekanan darah tinggi/rendah, strok, anemia, leukimia atau kelainan darah lainnya, serta gangguan saluran kencing dan genital, meliputi kencing batu, kencing darah, ginjal, prostat, kandung kemih atau penyakit lainnya ketika mengajukan aplikasi permohonan asuransi jiwa.

Kemudian Tergugat menyatakan bahwa Bapak Erisman (Alm) tidak menyampaikan fakta sesuai kondisi kesehatannya dalam Surat Permintaan Asuransi Jiwa (SPAJ). Berdasarkan dokumentasi dan pengajuan klaim yang diajukan Penggugat, Tergugat mendapatkan fakta bahwa meninggalnya bapak Erisman (Alm) adalah karena Uremi Encephalopathy dengan gagal ginjal. Ketika Bapak Erisman (Alm) dirawat pada tanggal 28 januari 2012 sampai dengan 31 Januari 2012, ternyata terdapat Chronic Heat Failure (CHF) yang disebabkan hipertensi, Chronic Disease (CKD) Stage $V$ dan pada anamesia disebutkan adanya riwayat Acute Lung Oedem (gagal ginjal) yang diderita oleh Bapak Erisman (Alm) sekitar kurang lebih 2 tahun yang lalu.

Ketika Bapak Erisman (Alm) dirawat tersebut selama kurang lebih empat hari tersebut, seorang agen asuransi bernama Esther mendatangi nya dan menganjurkan supaya Penggugat membayar tunggakan asuransi Bapak Erisman (Alm) yang telah menunggak selama 6 bulan dengan alasan jika Bapak Erisman meninggal dunia, maka klaim nya dapat diurus oleh agen Esther. Namun pada pengisian formulir pemulihan polis tanggal 29 Januari 2012 (ketika Bapak Erisman dirawat di RS Yos Sudarso), tidak ada informasi bahwa Bapak Erisman sedang menjalani rawat inap dengan diagnosa $\mathrm{CHF}$ fc III ec Hipertensi dan CKG Stage V. Bahkan di dalam formulir pemulihan polis tersebut, Bapak Erisman (Alm) menulis Tidak untuk jawaban atas pertanyaan apakah pernah menderita penyakit nyeri dada, sesak napas, jantung berdebar-debar, serangan jantung, tekanan darah tinggi/rendah, strok, anemia, leukimia atau kelainan darah lainnya, serta gangguan saluran kencing dan genital, meliputi kencing batu, kencing darah, ginjal, prostat, kandung kemih atau penyakit lainnya.

Serta Penggugat menjawab Tidak ketika mengisi jawaban atas pertanyaan apakah tertanggung dalam 3 (tiga) tahun terakhir pernah mendapatkan pemeriksaan kesehatan/check up, elektrokardiogram (EKG), tredmill, rontgen, CT Stcan, USG, Biopsi, Pemeriksaan Laboratorium atau pemeriksaan diagnostic lainnya. Bapak Erisman (Alm) juga menjawab Tidak pada pertanyaan apakah terdapat pembedahan atau operasi tertentu, nasihat medis, rawat inap dirumah sakit dan atau untuk pengobatan lainnya. Kemudian dalam Surat Permintaan Asuransi Jiwa atau ketika pembukaan polis yang ditandatangani oleh Bapak Erisman (Alm) tertanggal 5 November 2010 juga tidak ada informasi mengenai bahwa Bapak Erisman (Alm) mengidap penyakit Acute Lung Oedem yang merupakan penyakit terkait gagal ginjal yang tidak timbul secara mendadak. 
Di dalam pasal 251 KUHD dikatakan bahwa;

"Setiap keterangan yang keliru atau tidak benar, atau pun setiap tidak memberitahukan hal-hal yang diketahui oleh Tertanggung, betatapun itikad baik ada padanya, yang demikian sifatnya, sehingga seandainya si Penanggung telah mengetahui keadaan yang sebenarnya, perjanjian itu tidak akan ditutup atau tidak ditutup dengan syaratsyarat yang sama, mengakibatkan batalnya pertanggungan"

Pelanggaran prinsip Utmost Good Faith sebagai dasar untuk menolak klaim tertanggung sudah tepat menurut hukum asuransi karena ketika melakukan penutupan asuransi bahkan ketika dilakukan pemulihan polis asuransi, Tertanggung misrepresentasi berupa memberikan keterangan yang tidak benar yakni Tertanggung menulis tidak pada pertanyaan apakah Tertanggung pernah menderita penyakit nyeri dada, sesak napas, jantung berdebar-debar, serangan jantung, tekanan darah tinggi/rendah, strok, anemia, leukimia atau kelainan darah lainnya, serta gangguan saluran kencing dan genital, meliputi kencing batu, kencing darah, ginjal, prostat, kandung kemih atau penyakit lainnya pada saat pengisian SPAJ. Kemudian ketika dilakukan pemulihan Polis asuransi Tertanggung juga memberikan keterangan tidak adanya masalah dengan kesehatan dirinya yang mana hal tersebut kontradiksi dengan kenyataan. Dalam resume RS Yos Sudarso Padang menyatakan bahwa Bapak Erisman (Alm) memiliki Chronic Heat Failure (CHF) yang disebabkan hipertensi, Chronic disease (CKD) Stage $V$ dan pada anamesia terdapat riwayat Acute Lung Oedem (gagal ginjal) yang telah diderita kurang lebih 2 (dua) tahun. Sedangkan ketika pengisian SPAJ atau bahkan ketika pemulihan Polis asuransi hal tersebut tidak disampaikan kepada penanggung sehingga Penanggung beranggapan bahwa Tertanggung tidak memiliki penyakit nyeri dada, sesak napas, jantung berdebar-debar, serangan jantung, tekanan darah tinggi/rendah, strok, anemia, leukimia atau kelainan darah lainnya, serta gangguan saluran kencing dan genital, meliputi kencing batu, kencing darah, ginjal, prostat, kandung kemih atau penyakit lainnya. Tentu nya jika pada pembukaan perjanjian asuransi Tertanggung memberitahukan bahwa ia menderita penyakit gagal ginjal, Maka pihak Penanggung pasti akan mempertimbangkan lagi Permohonan aplikasi yang diajukan Tertanggung tersebut. Karena Tertanggung memiliki risiko yang lebih besar daripada risiko orang lain pada jenis asuransi yang sama sehingga mungkin akan diperbesar nominal premi nya atau bahkan Penanggung mungkin saja menolak permohonan aplikasi tersebut.

Seharusnya Bapak Erisman (Alm) ketika pembukaan perjanjian asuransi, menyatakan bahwa ia memiliki riwayat penyakit gagal ginjal tersebut atau minimal ia memberitahukan nya ketika dilakukan pemulihan polis sehingga Penanggung merasa tidak dibohongi oleh Tertanggung. Karena jika Bapak Erisman (Alm) tidak memberitahukan bahwa ia memiliki riwayat penyakit gagal ginjal, hal tersebut dapat mengakibatkan batalnya pertanggungan. Jika Pertanggungan dinyatakan batal demi hukum, maka seluruh premi yang dibayarkan dapat dikembalikan, kecuali jika Tertanggung terbukti menipu.

\section{Analisis Dampak Hukum Penerapan Waiting Period Pada Polis Asuransi Nomor 000012400302 Atas Nama Erisman Terhadap Tanggung Jawab Polis.}

$$
\text { Bapak Erisman }
$$

mengasuransikan dirinya pada tanggal 15 November 2010 dengan nomor polis 000012400302 dengan nilai pertanggungan sebesar Rp. 100.000.000,- dan premi Rp. 500.000 ,- per bulan nya. Pada tanggal 29 Januari 2012 dilakukan pemulihan polis asuransi karena Tertanggung telah menunggak selama 6 bulan. Total Premi yang telah dibayarkan Tertanggung adalah 17 x Rp. 500.000,- = Rp. 8.500.000,- dengan rincian 16x dibayar oleh Penggugat dan $1 \mathrm{x}$ dibayar oleh agen asuransi Esther. Dalam pertimbangan hukum nya, Majelis Hakim mengutip Pasal 2 tentang Dasar Pertanggungan Polis Asuransi Jiwa Smartlink yakni; 
Ayat (1) : Sebagai syarat penerbitan polis, Anda wajib untuk mengisi dengan benar dan lengkap semua keterangan dan pernyataan pada SPAJ dan formulir-formulir yang kami sediakan serta menandatangani SPAJ dan formulir-formulir tersebut. Semua keterangan dan pernyataan yang telah diberikan kepada kami menjadi tanggung jawab anda. Seluruh SPAJ, formulir data, keterangan merupakan satu kesatuan yang tidak terpisahkan dari polis.

Ayat (2) : Kami berhak membatalkan polis serta tidak membayarkan maslahat meninggal, apabila dikemudian hari kami ketahui bahwa keterangan dan pernyataan yang diisikan dalam SPAJ dan formulirformulir tersebut tidak sesuai dengan keadaan atau kondisi yang sebenarnya, atau dengan sengaja dipalsukan, kecuali apabila Pertanggungan telah berlaku lebih dari 2 (dua) tahun sejak tanggal polis atau tanggal pemulihan polis, mana yang lebih akhir.

Kemudian dalam pertimbangan hukum nya, Pemulihan polis efektif mulai berlaku sejak 15 Februari 2012 dan premi berikutnya jatuh tempo pada tanggal 15 Maret 2012. Namun tanpa diduga ternyata Bapak Erisman (Alm) meninggal dunia pada tanggal 14 Maret 2012 atau sekitar 1 (satu) bulan setelah pemulihan polis yang dilakukan Bapak Erisman ketika dirawat di RS Yos Sudarso Padang. Dampak hukum penerapan waiting period pada polis asuransi nomor 000012400302 atas nama Erisman terhadap tanggung jawab polis yaitu Tergugat memiliki hak untuk membatalkan polis serta tidak membayarkan maslahat meninggal sebagaimana ketentuan pasal 2 ayat (2) Polis asuransi jiwa smartlink tersebut.

Di dalam pasal 1338 KUHPerdata, dikatakan bahwa Semua perjanjian yang dibuat secara sah berlaku sebagai undangundang bagi mereka yang membuatnya. Polis asuransi dengan nomor 000012400302 atas nama Erisman mengikat bagi Erisman dan Perusahaan asuransi (PT. Allianz Life Indonesia) layaknya undang-undang bagi mereka. Kemudian pada baris kedua pasal 1338 KUHPerdata, dikatakan bahwa suatu perjanjian tidak dapat ditarik kembali selain dengan sepakat kedua belah pihak, atau karena alasan-alasan yang oleh undang-undang dinyatakan cukup untuk itu. Mengingat Tertanggung telah meninggal dunia pada tanggal 14 Maret 2012, ketika Polis asuransi baru berumur kurang lebih 1 tahun 6 bulan (18 bulan) atau ketika pemulihan polis asuransi baru berumur 1 bulan maka pihak Tergugat berhak untuk membatalkan polis asuransi dan tidak membayarkan maslahat meninggal jika keterangan dan pernyataan yang diisikan dalam SPAJ dan formulir-formulir tidak sesuai dengan keadaan yang sebenarnya, kecuali pertanggungan telah berlaku selama 2 tahun sejak tanggal polis atau tanggal pemulihan polis, mana yang lebih akhir sebagaimana ketentuan pasal 2 ayat (2) tentang Dasar Pertanggungan Polis Asuransi Jiwa Smartlink. Majelis hakim seharusnya mempertanyakan peranan agen dalam kasus ini karena ketika bapak Erisman dirawat pada tanggal 29 Januari 2012, agen asuransi bernama Esther menawarkan bapak Erisman untuk dilakukan pemulihan polis asuransi yang telah menunggak selama 6 bulan. Karena telah dibujuk oleh agen asuransi untuk dilakukan pemulihan polis asuransi, akhirnya bapak Erisman menyetujui nya dan ia mengisi formulir pemulihan polis asuransi. Ketika mengisi formulir pemulihan polis asuransi, bapak Erisman menjawab tidak pada pertanyaan apakah Tertanggung pernah menderita penyakit nyeri dada, sesak napas, jantung berdebar-debar, serangan jantung, tekanan darah tinggi/rendah, strok, anemia, leukimia atau kelainan darah lainnya, serta gangguan saluran kencing dan genital, meliputi kencing batu, kencing darah, ginjal, prostat, kandung kemih atau penyakit lainnya. Lalu bapak Erisman juga menjawab tidak pada pertanyaan apakah Tertanggung dalam 3 tahun terakhir pernah mendapatkan pemeriksaan kesehatan/check up, elektrodiogram (EKG), rontgen, CT Scan, USG, Biopsi, pemeriksaan laboratorium atau pemeriksaan diagnostic lainnya. Jawaban yang sama juga disampaikan oleh bapak Erisman untuk pertanyaan apakah ada pembedahan/operasi tertentu, nasihat medis, rawat inap dirumah sakit dan atau untuk pengobatan. 


\section{Analisis Penerapan Prinsip Utmost Good Faith dalam Putusan no. 138/pdt.g/2012/Pn.Pdg.}

\begin{tabular}{lllr} 
Dalam & kasus, & \multicolumn{2}{c}{ Tertanggung } \\
mengungkapkan & bahwa & ketika ia \\
mengasuransikan & dirinya, ia & menyatakan
\end{tabular}
bahwa dirinya sehat dan Tertanggung telah melakukan pengecekan kesehatan oleh dokter yang ditunjuk oleh Tergugat. Dari hasil pemeriksaan tersebut Tertanggung terbebas dari penyakit nyeri dada, sesak napas, jantung berdebar-debar, serangan jantung, tekanan darah tinggi/rendah, stroke, anemia, leukimia, atau kelainan darah lainnya serta ganggugan saluran kencing dan genital, meliputi kencing batu, kencing darah, ginjal, prostat, kandung kemih atau penyakit lainnya. Kemudian Tergugat menyatakan bahwa Tertanggung ketika melakukan pengisian SPAJ tidak memberikan keterangan yang sebenarnya, dibuktikan dengan diagnosa dari RS Yos Sudarso Padang yang menyatakan bahwa Tertanggung menderita penyakit Acute Lung Oedem (gagal ginjal) yang telah dialami selama kurang lebih dua tahun. Kemudian sempat terjadi Pemulihan Polis asuransi karena Tertanggung sempat menunggak membayar premi asuransi selama 6 bulan. Ketika pengisian formulir Pemulihan asuransi, Tertanggung sedang dirawat di RS Yos Sudarso dengan diagnosa bahwa ia memiliki penyakit Chronic Heat Failure (CHF) yang disebabkan hipertensi, Chronic Disease (CKD) stage $V$ dan pada anamesia disebutkan adanya riwayat Acute Lung Oedem (gagal ginjal) yang telah diderita selama kurang lebih dua tahun tersebut.

Tetapi di dalam formulir pemulihan asuransi tersebut, Tertanggung menyatakan tidak atas jawaban pada pertanyaan apakah pernah menderita penyakit sebagaimana yang disebutkan pada uraian angka 16 jawaban tergugat diatas. Bahkan Penggugat juga menjawab tidak atas jawaban pada pertanyaan apakah Tertanggung dalam 3 tahun terakhir pernah mendapatkan pemeriksaan kesehatan/check up, elektrokardiogram (EKG), tredmill, rontgen, CT Scan, USG, Biopsi, Pemeriksaan Laboratorium atau pemeriksaan diagnostic lainnya. Tertanggung juga menyatakan tidak atas jawaban pada pertanyaan apakah terdapat pembedahan atau operasi tertentu, nasihat medis atau rawat inap di rumah sakit dan atau untuk pengobatan.

Hal ini bertolak belakang dengan fakta yang ada yakni pada tanggal 28 Januari 2012 sampai dengan 31 Januari 2012 Tertanggung sedang dirawat di RS Yos Sudarso karena adanya riwayat Acute Lung Oedem (gagal ginjal). Mengingat penyakit gagal ginjal itu tidak datang secara tiba-tiba, bahkan menurut diagnosa RS Yos Sudarso Padang menyatakan bahwa riwayat penyakit tersebut kurang lebih telah di derita selama 2 tahun, tetapi Tertanggung tidak memberitahukan nya ketika melakukan Penutupan asuransi. Ketika Pemulihan polis asuransi tanggal 29 Januari 2012 juga Tertanggung tidak menyatakan bahwa ia sedang menderita penyakit.

Perbuatan Tertanggung tersebut termasuk dalam misrepresentasi berupa keterangan yang tidak benar karena Tertanggung tidak memberikan informasi yang sesuai dengan fakta bahwa ia menderita penyakit gagal ginjal. Misrepresentasi ini ada yang dapat mengakibatkan batalnya pertanggungan dan ada pula yang tidak mengakibatkan batalnya pertanggungan. Misrepresentasi yang dapat mengakibatkan batalnya pertanggungan adalah misrepresentasi yang disengaja dan bertujuan untuk mengelabui Penanggung (Material Misrepresentation). Sedangkan misrepresentasi yang tidak membatalkan pertanggungan adalah misrepresentasi yang tidak disengaja dan tidak ada niat untuk mengelabui penangggung (Immaterial Misrepresentation)

Perbuatan Tertanggung ini termasuk dalam misrepresentasi yang dapat mengakibatkan batal nya pertanggungan karena ia jelas-jelas mengelabui penanggung pada saat pemulihan polis asuransi. Ia memberikan informasi pada formulir pemulihan polis bahwa ia tidak pernah menderita penyakit dan lain lain, padahal jelas-jelas ia sedang dirawat di RS Yos Sudarso Padang karena memiliki riwayat penyakit gagal ginjal. Kemudian jika kita lihat dalam Putusan Pengadilan No 138/Pdt.g/2012/Pn.Pdg, Majelis Hakim 
menolak gugatan Penggugat seluruhnya karena mempertimbangkan klausul Polis asuransi pada pasal pasal 2 Tentang Dasar Pertanggungan Polis Asuransi Smartlink;

Ayat (1) : Sebagai syarat penerbitan polis, anda wajib untuk mengisi dengan benar dan lengkap semua keterangan dan pernyataan pada SPAJ dan formulir-formulir yang kami sediakan serta menandatangani SPAJ dan formulir-formulir tersebut. Semua keterangan dan pernyataan yang telah diberikan kepada kami menjadi tanggung jawab anda. Seluruh SPAJ, formulir, data, keterangan tersebut merupakan satu kesatuan yang tidak terpisahkan dari polis.

Ayat (2) : Kami berhak membatalkan polis serta tidak membayarkan maslahat meninggal, apabila dikemudian hari kami ketahui bahwa keterangan dan pernyataan yang diisikan dalam SPAJ dan formulirformulir tersebut tidak sesuai dengan keadaan atau kondisi yang sebenarnya, atau dengan sengaja dipalsukan, kecuali apabila Pertanggunga telah berlaku lebih dari 2 (dua) tahun sejak tanggal polis atau tanggal pemulihan polis, mana yang lebih akhir.

Pada pasal 2 ayat (2) Polis asuransi Smartlink tersebut, Tergugat berhak tidak membayarkan maslahat meninggal jika ditemukan keterangan dan pernyataan yang tidak sesuai dengan fakta. Jika merujuk pada ketentuan tersebut, sudah sangat jelas bahwa Penanggung tidak wajib memberikan uang pertanggungan ketika Tertanggung meninggal dunia. Namun di dalam Putusan Pengadilan No 138/Pdt.g/2012/Pn.Pdg tersebut, Majelis Hakim belum menerapkan prinsip Utmost Good Faith karena masa polis Tertanggung belum melewati dua tahun baik ketika penutupan polis maupun ketika pemulihan polis asuransi sebagaimana pasal 2 ayat (2) ketentuan polis asuransi, serta Penggugat tidak dapat membuktikan dalil gugatannya di pengadilan sehingga dalil-dalil Tergugat mengenai pelanggaran prinsip Utmost Good Faith dianggap tidak ada relevansi nya untuk mempertimbangkannya.

\section{KESIMPULAN (12pt)}

Berdasarkan uraian diatas, penulis menyimpulkan sebagai berikut:
1. Pelanggaran prinsip Utmost Good Faith sebagai dasar untuk menolak klaim tertanggung dalam sengketa asuransi jiwa antara Endry Suryanti melawan PT. Asuransi Allianz Life Indonesia sudah tepat menurut hukum asuransi, tetapi kurang mendalam dalam pertimbangan hukum oleh hakim.

2. Dampak hukum waiting period dari polis asuransi nomor 000012400302 atas nama Erisman terhadap tanggung jawab polis adalah penanggung berhak membatalkan polis asuransi serta tidak membayar maslahat (manfaat/klaim) meninggal karena data dalam SPAJ dan formulir yang diisi oleh Tertanggung tidak sesuai dengan keadaan yang sebenarnya serta pertanggungan belum berjalan dua tahun sejak tanggal polis atau pemulihan polis serta majelis hakim seharusnya mempertanyakan peranan agen asuransi dalam kasus ini.

3. Di dalam putusan pengadilan nomor 138/Pdt.g/2012/Pn.Pdg, Majelis Hakim belum menerapkan Prinsip Utmost Good Faith karena tidak ada relevansinya di dalam pertimbangan hukum putusan tersebut mengingat masa polis asuransi Erisman belum mencapai dua tahun sebagaimana ketentuan pasal 2 ayat (2) Polis Asuransi dan Penggugat tidak dapat membuktikan dalil gugatannya di dalam persidangan.

\section{SARAN}

penulis memberikan saran untuk kedepannya yaitu sebagai berikut:

1. Sebaiknya jika menggunakan jasa asuransi, berikan keterangan yang sesuai dengan fakta supaya tidak mengakibatkan klaim tidak dijamin dan polis batal demi hukum.

2. Sebelum mengajukan SPAJ, sebaiknya diperhatikan klausul-klausul didalamnya. Jika terdapat klausul-klausul yang tidak dimengerti, jangan sungkan untuk menanyakan nya kepada Penanggung supaya Tertanggung dapat mengerti dengan baik mengenai isi polis asuransi tersebut. 


\section{DAFTAR PUSTAKA}

Amrin, Abdullah, (2011). Meraih berkah melalui Asuransi Syariah ditinjau dari perbandingan dengan Asuransi Konvensional (p.1). Jakarta: PT. Elex Media Komputindo.

Anwar, Moch dan fathuddin,(1993). Kamus Umum Asuransi (p.78) Jakarta: Kesaint Blanc.

Ayat, Safri, (1995). Kamus Praktik Asuransi (p. 125). Jakarta : Pusat Pembinaan dan Pengembangan Bahasa Departemen Pendidikan dan Kebudayaan.

Hartono, Sri Rejeki, (1995). Hukum asuransi dan Perusahaan Asuransi (p.64). Jakarta: Sinar Grafika.

Kitab Undang-Undang Hukum Dagang [Wetboek van Koophandel]. Diterjemahkan oleh R. Subekti dan R. Tjirosudibio, Jakarta: PT Pradnya Paramitha, 2016.

Kitab Undang-Undang Hukum Perdata (Burgerlijk Wetboek). Diterjemahkan oleh R. Subekti dan R. Tjirosudibio, Jakarta: PT Balai Pustaka, 2014.

Mengenal Surat Permintaan Asuransi Jiwa, diakses tanggal 12 Oktober 2020, https://www.finansialku.com/menge nal-spaj-surat-permintaan-asuransijiwa/..

Prodjodikoro, Wirjono, (1979). Hukum Asuransi di Indonesia (p.1). Jakarta : PT Intermasa.

Simanjuntak, Kornelius, Brian Amy Prastyo, Myra R.B Setiawan, (2011). Hukum Asuransi (p.31-38). Depok :

Djokosoetono Research Center FHUI.

Subekti, R dan R. Tjitrosudibio, (1970). Kamus Hukum (p.89). Jakarta: Pradnya Paramita.

Sunggono, Bambang, (1997). Metodologi Penelitian Hukum (p.81). Jakarta: Rajagrafindo Persada.

Sunyoto, Danang dan Wika harisa putri, (2017). Manajemen Risiko dan Asuransi (p.1). Yogyakarta: Center for Academic Publishing Service.
Undang-Undang Republik Indonesia Nomor 40 Tahun 2014 tentang Perasuransian. 